\title{
IMPLEMENTASI PRINSIP KEHATI-HATIAN DALAM PERBANKAN
}

\author{
Caution Implementation Principles In Banking
}

\author{
Imas Khaeriyah Primasari \\ Fakultas Hukum Unwir \\ primasari250179@gmail.com
}

\section{ABSTRAK}

Perbankan sebagai lembaga keuangan rentan dengan berbagai risiko oleh sebab itu, karena fungsi bank maka, perlu diterapkan prinsip kehatihatian dalam dunia perbankan. Peranan bank sebagai lembaga keuangan tidak pernah lepas dari masalah pembiayaan. Bahkan kegiatan bank sebagai lembaga keuangan, pemberian pembiayaan adalah kegiatan utamanya, permasalahan 1. Bagaimanakah Pengaturan Prinsip kehati-hatian dalam Undang-undang Perbankan? 2 Bagaimanakah Implementasi Prinsip Kehati-hatian Dalam Hukum Perbankan, Tinjaun Pustaka Pengertian Prinsip Kehati-Hatian Prinsip Kehati-hatian berasal dari kata "hati-hati" (prudent) yang erat kaitannya dengan fungsi pengawasan bank dan manajemen bank. Prudent dapat juga diterjemahkan dengan bijaksana, namun dalam dunia perbankan istilah itu digunakan dan diterjemahkan dengan hati-hati atau kehati-hatian, hasil penelitian menyatakan bahwa Pengaturan Prinsip Kehati-hatian (Prudential Prindiple) Dalam Undang- undang Perbankan pasal 2 Undang-undangf Nomor 10 Tahun 1988 sebagai perubahan atas Undangundang Nomor 7 Tahun 1992 tentang perbankan, bahwa perbankan Indonesia dalam melakukan usahanya berasaskan demokrasi ekonomi dengan menggunakan prinsip kehati-hatian. Ada satu pasal dalam Undang-undang Perbankan, yang secara eksplisit mengandung subtansi prinsip kehati-hatian, yakni pasal 29 ayat 2,3 dan 4 Undang-undang Nomor 10 Tahun 1998, UndangUndang Nomor 23 Tahun 1999 tentang Bank Indonesia pasal 25 ayat 1 mengatur mengenai wewenang Bank Indonesia untuk mengatur mengenai prinsip kehati-hatian bagi usaha bank dengan menyatakan bahwa "Dalam rangka melaksanakan tugas mengatur bank, Bank Indonesia berwenang menetapkan ketentuanketentuan perbankan yang memuat prinsip kehati - hatian. Implementasi prinsip kehati-hatian dalam hukum perbankan Pada ayat (1) dijelaskan bahwa ketentuan-ketentuan perbankan yang memuat prinsip kehati-hatian bertujuan untuk memberikan rambu-rambu bagi penyelenggaraan kegiatan usaha perbankan guna mewujudkan
\end{abstract}

sistem perbankan yang sehat. Mengingat pentingnya tujuan mewujudkan sistem perbankan yang sehat, maka peraturan-peraturan di bidang perbankan yang ditetapkan oleh Bank Indonesia harus didukung dengan sanksi-sanksi yang adil. Pengaturan bank berdasarkan prinsip kehatihatian tersebut disesuaikan pula dengan standar yang berlaku secara internasional.

Kata Kunci: Lembaga Keungan, Prinsip Kehatihatiab, Perbankan

\section{ABSTRACT}

Banking as a financial institution is vulnerable to a variety of risks, therefore, because of the bank's function, the principle of prudence must be applied in the banking world. The role of banks as financial institutions has never been separated from financing problems. Even the activities of banks as financial institutions, providing financing are the main activities, problems 1 . What is the regulation of the precautionary principle in the Banking Law? 2 How Implementation of the Precautionary Principle in Banking Law, Literature Review Understanding the Precautionary Principle The Precautionary Principle comes from the word "prudent" which is closely related to the function of bank supervision and bank management. Prudent can also be translated wisely, but in the world of banking the term is used and translated with caution or caution, the results of the study state that the Regulation of the Prudential Principle in the Banking Law article 2 of Act Number 101988 as a change to Law Number 7 of 1992 concerning banking, that Indonesian banks in carrying out their business based on economic democracy by using the principle of prudence. There is one article in the Banking Law, which explicitly contains the substance of the precautionary principle, namely article 29 paragraph 2.3 and 4 of Act Number 10 of 1998, Law Number 23 of 1999 concerning Bank Indonesia article 25 paragraph 1 regulates the authority of Bank Indonesia to regulate the precautionary principle for the bank's business by stating that "In order to carry out the task of regulating banks, Bank Indonesia has the authority 
to stipulate banking provisions which contain the principle of prudence. Implementation of prudential principles in banking law In paragraph (1), it is explained that banking provisions which contain the principle of prudence aim to provide signs for the conduct of banking business activities in order to realize a healthy banking system. Given the importance of the goal of realizing a healthy banking system, the regulations in the banking sector stipulated by Bank Indonesia must be supported by fair sanctions. Bank regulation based on the precautionary principle is also adjusted to international standards.

Keywords: Financial Institutions, Prudential Principles, Banking.

\section{PENDAHULUAN}

Perekonomian Indonesia tidak lepas dari adanya peran perbankan, di mana perbankan berfungsi sebagai penghimpun dan penyalur dana kepada masyarakat. Baik kepada usaha yang bersifat kecil, menengah dan besar. Perkembangan peran bank sebagai lembaga keuangan sangat besar dalam mendorong pertumbuhan ekonomi suatu negara. Semua sektor baik industri, perdagangan, perkebunan, pertanian, jasa dan lainnya sangat membutuhkan bank sebagai mitra dalam mengembangkan usahanya. Maka dari itu peran perbankan harus lebih ditingkatkan mengingat perbankan adalah badan usaha yang menghimpun dana dari mesyarakat dalam bentuk simpanan dan menyalurkan ke masyarakat dalam bentuk pembiayaan dalam rangka meningkatkan taraf hidup rakyat sesuai dalam UU No.10 tahun 1998.

Perbankan sebagai lembaga keuangan rentan dengan berbagai risiko oleh sebab itu, karena fungsi bank yang demikian, maka perlu diterapkan prinsip kehati-hatian dalam dunia perbankan. Peranan bank sebagai lembaga keuangan tidak pernah lepas dari masalah pembiayaan. Bahkan kegiatan bank sebagai lembaga keuangan, pemberian pembiayaan adalah kegiatan utamanya. Besar jumlah pembiayaan yang disalurkan akan menentukan keuntungan bank. Jika bank tidak mampu menyalurkan pembiayaan sementara dana yang dihimpun dari simpanan banyak maka akan menyebabkan bank tersebut rugi. Oleh karena itu, pengelolaan pembiayaan harus dilakukan dengan sebaikbaiknya mulai dari perencanaan jumlah kredit, penentuan margin, prosedur pemberian pembiayaan, analisis pemberian pembiayaan sampai pada pengendalian pembiayaan macet Sektor perbankan yang memiliki posisi strategis sebagai lembaga intermediasi dan sistem pembayaran diharapkan akan dapat memperbaiki dan memperkukuh perekonomian nasional.

Penerapan prinsip kehati-hatian ( Prudent Banking) adalah suatu asas atau prinsip yang menyatakan bahwa bank dalam menjalankan fungsi dan kegiatan usahanya wajib bersikap hati-hati dalam rangka melindungi dana masyarakat yang dipercayakan padanya. Pelaksanaan prinsip kehati-hatian dalam proses pembiayaan dalam praktek dilakukan dengan melakukan proses analisis terhadap permohonan pembiayaan yang dilakukan oleh debitur, namun prinsip kehati-hatian 
Imas Khaeriyah Primasari

dalam proses pemberian pembiayaan dalam praktek seringkali karakter atau watak ataupun mental debutir yang kurang baik, debitur masih menyelewengkan atau menyalahgunakan kepercayaan yang telah diberikan oleh Bank, pada awal pengajuan pembiayaan debitur mematuhi segala aturan yang ada, namun setelah pembiayaan dicairkan mulailah nampak karakter atau watak debitur yang menunjukkan tidak baik, untuk menghindari hal yang demikian sangat perlu diperhatikan kejujuran dan itikad baik debitur, bagaimanapun manajemen perbankan akan sangat mengambil peran dalam perwujudan selanjutnya dan dibutuhkan sumber daya manusia yang kuat, teliti dalam menganalisis dan mempunyai mental yang tangguh, namun tetap komit terhadap pemberian pembiayaan yang cepat dan hati-hati.

Dalam prakteknya masih banyak bank-bank yang terkendala masalah. Salah satu faktornya adalah akibat perilaku para pengelola dan pemilik bank yang cenderung mengeksploitasi dan atau mengabaikan prinsip kehati-hatian (prudential banking principle)

Dari urian di atas, maka terdapat beberapa permasalahan yang akan dibahas dalam penelitian ini :

1. Bagaimanakah Pengaturan Prinsip kehatihatian dalam Undang-undang Perbankan?
2. Bagaimanakah Implementasi Prinsip

Kehati-hatian Dalam Hukum Perbankan

\section{TINJAUAN PUSTAKA}

1.Pengertian Prinsip Kehati-hatian

Prudential Prindiple)

Pengertian Prinsip Kehati-Hatian Prinsip Kehati-hatian berasal dari kata "hati-hati" (prudent) yang erat kaitannya dengan fungsi pengawasan bank dan manajemen bank. Prudent dapat juga diterjemahkan dengan bijaksana, namun dalam dunia perbankan istilah itu digunakan dan diterjemahkan dengan hati-hati atau kehati-hatian.

Jadi prinsip kehati-hatian perbankan (prudent banking principle) merupakan suatu asas atau prinsip yang menyatakan bahwa bank atau lembaga dalam menjalankan fungsi dan kegiatan usahanya wajib menerapkan prinsip kehati-hatian (prudent) dengan mengenal customer dalam rangka melindungi dana masyarakat yang dipercayakan padanya, dengan mengharapkan kadar kepercayaan masyarakat terhadap lembaga keuangan tetap tinggi, sehingga masyarakat bersedia dan tidak ragu-ragu menyimpan dananya di bank. Prinsip kehati-hatian adalah suatu asas atau prinsip yang menyatakan bahwa bank dalam menjalankan fungsi dan kegiatan usahanya wajib bersikap hati-hati dalam rangka melindungi dana masyarakat yang dipercayakan padanya. Hal ini disebutkan dalam pasal 2 UU Nomor 10 tahun 1998 sebagai perubahan atas UU Nomor 7 tahun 
Imas Khaeriyah Primasari

1992 Tentang Perbankan, bahwa perbankan indonesia dalam melakukan usahanya berasaskan demokrasi ekonomi dengan menggunakan prinsip kehati-hatian. Dalam ketentuan ini menunjukan bahwa prinsip kehati-hatian adalah asas terpenting yang wajib diterapkan atau dilaksanakan oleh bank dalam menjalankan kegiatan usahanya. Dalam arti harus selalu konsisten dalam melaksanakan peraturan perundangundangan di bidang perbankan berdasarkan profesionalisme dan itikad baik.

2.Penerapan Prinsip Kehati-hatian Dalam Pembiayaan

Apabila Undang-Undang No 7 Tahun 1992 tentang Perbankan belum secara eksplisit menentukan bahwa kegiatan-kegiatan usaha bank bagi hasil harus pula memperhatikan prinsip kehati-hatian (prudential principle) yang operasionalnya dijabarkan kedalam rambu-rambu kesehatan bank (prudentialstandards) yang secara tegas diberlakukan bagi bank konvensional, maka dalamUndang-Undang No. 10 Tahun 1988 yang merupakan perubahan terhadap beberapa ketentuan dalam Undang-Undang No. 7 Tahun 1992 itu telah dengan tegas menentukan bahwa prinsip dan rambu-rambu tersebut harus pula diperhatikan dan dipatuhi oleh bank-bank yang melakukan kegiatannya berdasarkan Prinsip Syariah. Demikian pula, hal ini ditegaskan dalam surat-surat keputusan direksi Bank Indonesia yang merupakan ketentuan-ketentuan pelaksanaan dari Undang-Undang No. 10 Tahun 1998 tersebut

\section{PEMBAHASAN}

1. Pengaturan Prinsip Kehati-hatian (Prudential Prindiple) Dalam Undangundang Perbankan

Pengertian Prinsip Kehati-Hatian Prinsip Kehati-hatian adalah suatu usaha asas atau prinsip yang menyatakan bahawa bank dalam menjalankan fungsi dan kegiatan usahanya yang wajib bersikap hati-hati dalam dunia perbankan (preudent) dalam rangka melindungi dana masyarakat yang dipercayakan padanya. Hal ini disebutkan dalam pasal 2 Undang-undangf Nomor 10 Tahun 1988 sebagai perubahan atas Undangundang Nomor 7 Tahun 1992 tentang perbankan, bahwa perbankan Indonesia dalam melakukan usahanya berasaskan demokrasi ekonomi dengan menggunakan prinsip kehati-hatian.

Ada satu pasal dalam Undang-undang Perbankan, yang secara eksplisit mengandung subtansi prinsip kehati-hatian, yakni pasal 29 ayat 2,3 dan 4 Undang-undang Nomor 10 Tahun 1998

Undang-Undang Nomor 23 Tahun 1999 tentang Bank Indonesia pasal 25 ayat 1 mengatur mengenai wewenang Bank Indonesia untuk mengatur mengenai prinsip kehati-hatian bagi usaha bank dengan menyatakan bahwa "Dalam rangka melaksanakan tugas mengatur bank, Bank 
Imas Khaeriyah Primasari

Indonesia berwenang menetapkan ketentuanketentuan perbankan yang memuat prinsip kehati - hatian."

Ketentuan-ketentuan perbankan yang memuat prinsip kehati-hatian bertujuan untuk memberikan rambu-rambu bagi penyelenggaraan kegiatan usaha perbankan guna mewujudkan sistem perbankan yang sehat. Mengingat pentingnya tujuan tersebut maka peraturan-peraturan mengenai prinsip kehati-hatian yang ditetapkan Bank Indonesia harus disesuaikan dengan standar internasional dan harus didukung dengan sanksi - sanksi yang adil.13

Oleh Undang-Undang Perbankan sama sekali tidak dijelaskan apa yang dimaksud dengan prinsip kehati-hatian, baik dalam bagian ketentuan maupun dalam penjelasannya. Undang-Undang Perbankan hanya menyebutkan istilah dan ruang lingkupnya saja sebagaimana dijelaskan dalam pasal 8 dan pasal 29 Undang-Undang Perbankan Nomor 10 Tahun 1998 serta pasal 25 ayat 1 Undang-Undang Nomor 23 Tahun 1999 tentang Bank Indonesia di atas. Oleh karena itu, pengertian prinsip kehati-hatian berdasarkan penjelasan diatas jelas sekali bahwa kewajiban melaksanakan prinsip kehati-hatian merupakan solusi terbaik dalam rangka menjaga dan mempertahankan eksistensi perbankan karena akan menumbuhkan kepercayaan masyarakat kepada industri perbankan itu sendiri.Penyimpangan atas prinsip, kehati- hatian yang dilakukan oleh pihak bank dalam penyaluran pembiayaan tersebut maupun yang berkaitan dengan pembebananagunan atau jaminan pembiayaan yang disalurkan pihak bank kepada debitur, seringkali berdampak menimbulkan kerugian bagi pihak bank sendiri, bahkan lebih jauh sangat dimungkinkan untuk dapat merugikan pihak ketiga diluar perjanjian pembiayaan tersebut terutama pihak ketiga yang memiliki kepentingan atas objek jaminan pembiayaan/pembiyayaan.

1.Resiko Perbankan Dalam Memberikan Pembiayaan

Pembiayaan dalam bank-bank kovensional dan bank syariah dalam memberikan pembiayaan memiliki resiko:

a. Resiko Pembiayaan (Credit Risk)

Resiko pembiayaan adalah resiko yang terjadi akibat kegagalan pihak lawan (counterparty) memenuhi kewajibannya, tidak bisa memperoleh cicilan pokok dan / atau bunga dari pinjaman yang diberikan atau investor yang sedang dilakukannya, sehingga mengakibatkan menurunnnya pendapatan yang dapat merupakan akibat dari kerugian atas pembiayaan (jual beli tangguh) atau kegagalan tagihan atas surat-surat berharga. Bank dapat mengendalikan resiko pembiayaan melalui pelaksanaan kegiatan usaha yang konservatif, meskipun terhadap bidang-bidang yang menjanjikan tingkat keuntungan yang sangat menarik. 
Resiko pembiayaan dapat ditekan dengan cara memberi bataswewenang keputusan pembiayaan bagi setiap aparat perpembiayaanan, berdasarkan kemampuannya dan batas jumlah pembiayaan yang dapat diberikan pada perusahaan atau usaha tertentu, serta melakukan diversifikasi.

Penyebab utama resiko ini adalah bank terlalu mudah memberikanpinjaman atau melakukan investasi. Hal ini dilakukan semata-mata untu memanfaatkan kelebihan likuiditas, sehingga penilaian pembiayaan kurangcermat.

\section{b. Capital Risk}

Resiko modal merefleksikan tingkat lavarage yang dipakai oleh bank. Salah satu fungsi modal adalah melindungi para penyimpan dana terhadap kerugian yang terjadi pada bank. Resiko modal sangat terkait dengan kualitas aset. Bank menggunakan sebagian besar dananya pada asset yang beresiko perlu memiliki modal penyangga yang besar untuk sandaran bila kinerja aset-aset yang tidak baik. Tujuan pembiayaan adalah untuk mengembangkan pembangunan berdasarkan prinsip-prinsip ekonomi yaitu dengan pengorbanan yang sekecil-kecilnya dapat diperoleh keuntungan yang sebesar-besarnya, maka pada umumnya tujuan pembiayaan adalah untuk memperoleh keuntungan.

Pembiayaan yang diberikan oleh pihak bank tersebut mengandung resiko yang besar bagi pihak bank sendiri, sehingga dalam pelaksanaannya bank harus memperhatikan asas-asas pembiayaanan yang sehat. Asasasas pembiayaanan yang sehat yang harus dipedomani oleh pihak bank tersebut diantaranya 1 . bank tidak diperkenankan memberikan pembiayaan tanpa surat perjanjian tertulis.2. bank tidak diperkenankan memberikan pembiayaan kepada usaha yang sejaksemula telah diperhitungkan kurang sehat dan akan membawa kerugian.

2.Implementasi Prinsip kehati-hatian Dalam Perbankan

Pengaturan prinsip kehati-hatian (Prudential Banking Principle) dapat dilihat dalam Undang-Undang nomor 23 Tahun 1999 tentang Bank Indonesia Pasal 25, dimana dalam pasal tersebut terdiri dari 2 ayat yang berisi:

1.Dalam rangka melaksanakan tugas mengatur bank, Bank Indonesia berwenang menetapkan ketentuan-ketentuan perbankan yang memuat prinsip kehati-hatian,

2. Pelaksanaan kewenangan sebagaimana dimaksud pada ayat (1) ditetapkan dengan Peraturan Bank Indonesia.

Adapun penjelasan dari kedua Pasal tersebut adalah sebagai berikut:

Pada ayat (1) dijelaskan bahwa ketentuanketentuan perbankan yang memuat prinsip kehati-hatian bertujuan untuk memberikan rambu-rambu bagi penyelenggaraan kegiatan usaha perbankan guna mewujudkan sistem perbankan yang sehat. Mengingat pentingnya 
Imas Khaeriyah Primasari

tujuan mewujudkan sistem perbankan yang sehat, maka peraturan-peraturan di bidang perbankan yang ditetapkan oleh Bank Indonesia harus didukung dengan sanksisanksi yang adil. Pengaturan bank berdasarkan prinsip kehati-hatian tersebut disesuaikan pula dengan standar yang berlaku secara internasional. Dan pada ayat (2) dijelaskan bahwa pokok-pokok dari berbagai ketentuan yang akan ditetapkan dalam Peraturan Bank Indonesia antara lain memuat:

a. perizinan bank;

b. kelembagaan bank, termasuk kepengurusan dan kepemilikan;

c. kegiatan usaha bank pada umumnya;

d. kegiatan usaha bank berdasarkan prinsip syariah;

e. merger, konsolidasi dan akuisisi bank;

f. sistem informasi antar bank;

g. tata cara pengawasan bank;

h. sistem pelaporan bank kepada Bank Indonesia;

i. penyehatan perbankan;

j. pencabutan izin usaha, likuidasi dan pembubaran bentuk hukum bank.

Pasal 2 Undang-Undang Nomor 10 tahun 1998 tentang Perubahan atas UndangUndang Perbankan Nomor 7 tahun 1992 tentang Perbankan, bahwa perbankan Indonesia dalam melakukan usahanya berasaskan demokrasi ekonomi dengan menggunakan prinsip kehati-hatian. Ada satu pasal dalam Undang-Undang Nomor 10 tahun 1998 tentang Perubahan atas UndangUndang Perbankan Nomor 7 tahun 1992 tentang Perbankan yang secara eksplisit mengandung substansi prinsip kehati-hatian, yakni Pasal 29 ayat (2), (3) dan (4).

Sebelum Bank memberikan kredit, bank harus melakukan penilaian yang saksama dan melaksanakan lima prinsip yang menjadi bagian dari prinsip kehati-hatian, yang dikenal dengan prinsip 5 C's, sebagai berikut: 1)Penilaian watak/kepribadian (Character) Penilaian watak atau kepribadian calon debitur dimaksudkan untuk mengetahui kejujuran dan itikad baik calon debitur untuk melunasi atau mengembalikan pinjamannya, sehingga tidak akan menyulitkan bank di kemudian hari. Hal ini dapat diperoleh terutama didasarkan kepada hubungan yang telah terjalin antara bank dan (calon) debitur atau informasi yang diperoleh dari pihak lain yang mengetahui moral, kepribadian dan perilaku calon debitur dalam kehidupan kesehariannya.

2) Penilaian kemampuan (Capacity) Bank harus meneliti tentang keahlian calon debitur dalam bidang usahanya dan kemampuan manajerialnya, sehingga bank yakin bahwa usaha yang akan dibiayainya dikelola oleh orangorang yang tepat, sehingga calon debiturnya dalam jangka waktu tertentu mampu melunasi atau mengembalikan pinjamannya. Kalau kemampuan bisnisnya kecil, tentu tidak layak diberikan kredit dalam 
skala besar. Demikian juga jika trend bisnisnya atau kinerja bisnisnya menurun, maka kredit juga semestinya tidak diberikan. Kecuali jika penurunan itu karena kekurangan biaya, sehingga dapat diantisipasi bahwa dengan tambahan biaya lewat peluncuran kredit, maka trend atau kinerja bisnisnya tersebut dipastikan akan semakin membaik.

3) Penilaian terhadap modal (Capital) Bank harus melakukan analisis terhadap posisi keuangan secara menyeluruh mengenai masa lalu dan yang akan datang, sehingga dapaat diketahui kemampuan permodalan calon debitur dalam menunjang pembiayaan proyek atau usaha calon debitur yang bersangkutan. Dalam praktek selama ini, bank jarang sekali memberikan kredit untuk membiayai seluruh dana yang diperlukan nasabah. Nasabah wajib menyediakan modal sendiri, sedangkan kekurangannya itu dapat dibiayai dengan kredit bank. Bank fungsinya hanya menyediakantambahan modal, dan biasanya lebih sedikit dari pokoknya.

4) Penilaian terhadap agunan (Collateral) Untuk menanggung pembayaran kredit macet dikarenakan debitur wanprestasi, maka calon debitur umumnya menyediakan jaminan berupa agunan yang berkualitas tinggi dan mudah dicairkan yang nilainya minimal sebesar jumlah kredit atau pembiayaan yang diberikan kepadanya. Untuk itu sudah seharusnya bank wajib meminta agunan tambahan dengan maksud jika calon debitur tidak dapat melunasi kreditnya, maka agunan tambahan tersebut dapat dicairkan guna menutupi pelunasan atau pengembangan kredit atau pembiayaan yang tersisa.

5) Penilaian terhadap prospek usaha nasabah debitur (Condition of economy) Bank harus menganalisis keadaan pasar di dalam dan di luar negeri, baik masa lalu maupun yang akan datang, sehingga masa depan pemasaran dari hasil proyek atau usaha calon debitur yang dibiayai dapat pula diketahui.

Meskipun UU Perbankan UU No. 10 Tahun 1998 tidak mensyaratkan adanya 'jaminan (collateral)', tetapi berdasarkan self regulatory banking (ketentuan perkreditan) yang berlaku pada masing-masing bank, jaminan tersebut mutlak diperlukan untuk menghindari resiko, mengingat secara represif kreditur dapat menyita dan melelang jaminan tersebut guna menutupi kewajiban debitur yang kreditnya macet (apabila debitur yang dalam perjanjiannyamenyertakan jaminan berupa agunan). Kekuasaan kreditur ini disebut beding vaaneigenmatigeverkoop, yang dilegalisir oleh Pasal 11 ayat (2) huruf e UU Hak Tanggungan Atas Tanah.33 Selain penerapan 5 (lima) kriteria yang dikenal dengan 5 C's seperti yang disebutkan di atas, maka dalam mengatisipasi terjadinya kredit bermasalah atau kredit macet, ada beberapa hal lain yang harus diterapkan oleh perbankan sebagai implementasi prinsip kehatihatian, sebagai berikut: 
1. Kewajiban penyusunan dan pelaksanaan perkreditan bank, yang meliputi:

a. Kebijakan tertulis mengenai kredit;

b. Perjanjian kredit.

2. Batas Maksimum Pemberian Kredit

3. Penilaian Kualitas Aktiva:

a. Penilaian 5 C's;

b. Satuan kerja penyelamatan kredit untuk menangani kredit bermasalah;

c. Perjanjian kredit (dispute settlemen

4. Sistem Informasi Debitur, mengenai:

a. Identitas debitur

b. Perjanjian kredit (representation and warranties).

5. Penerapan prinsip mengenal nasabah.

Dalam perspektif prinsip kehati-hatian (The prudential principle of banking), maka seluruh keputusan harus dilakukan dengan mengacu pada prinsip kehati-hatian, terutama setiap keputusan yang berhubungan dengan pengeluaran uang seperti penyaluran kredit.

Kasus kredit macet hingga menyebabkan 'collaps'nya sebuah bank menjadi bukti akan ketidak hati-hatian tersebut terjadi.

Penerapan atau implementasi prinsip kehatihatian dan kesehatan Bank dalam aspek perkreditan merupakan hal penting guna mewujudkan sistem perbankan yang sehat, dengan kata lain agar selalu dalam keadaan likuid dan solvent. Dengan diberlakukanya prinsip kehati-hatian diharapkan tingkat kepercayaan masyarakat terhadap perbankan tetap tinggi, masyarakat tidak ragu-ragu menaruh dananya di bank. Prinsip kehati- hatian harus dijalankan bukan hanya karena kewajiban bank agar tidak merugikan nasabah yang mempercayakan dananya kepada masyarakat, namun sebagai bagian dari sistem moneter yang menyangkut semua kepentingan masyarakat yang bukan hanya nasabah penyimpan dana dari bank itu saja. Maka dari itu prinsip dari kehati-hatian bertujuan agar menjalankan usahanya secara baik dan benar dengan mematuhi ketentuanketnetuan dan norma-norma hokum yang berlaku dalam dunia perbankan, agar bank yang bersangkutan selalu dalam keadaan sehat sehingga masyarakat semakin mempercayainya, yang pada giliranya akan mewujudkan sistem perbankan yang sehat dan efisien, dalam arti sempit dapat memelihara kepentingan masyarakat dengan baik, berkembang secara wajar dan bermanfaat bagi perkembangan ekonomi nasional

\section{KESIMPULAN}

1. Pengaturan Prinsip Kehati-hatian (Prudential Prindiple) Dalam Undangundang Perbankan pasal 2 Undang-undangf Nomor 10 Tahun 1988 sebagai perubahan atas Undang-undang Nomor 7 Tahun 1992 tentang perbankan, bahwa perbankan Indonesia dalam melakukan usahanya berasaskan demokrasi ekonomi dengan menggunakan prinsip kehati-hatian. Ada satu pasal dalam Undang-undang Perbankan, yang secara eksplisit mengandung subtansi 
Imas Khaeriyah Primasari

prinsip kehati-hatian, yakni pasal 29 ayat 2,3 dan 4 Undang-undang Nomor 10 Tahun 1998, Undang-Undang Nomor 23 Tahun 1999 tentang Bank Indonesia pasal 25 ayat 1 mengatur mengenai wewenang Bank Indonesia untuk mengatur mengenai prinsip kehati-hatian bagi usaha bank dengan menyatakan bahwa "Dalam rangka melaksanakan tugas mengatur bank, Bank Indonesia berwenang menetapkan ketentuanketentuan perbankan yang memuat prinsip kehati - hatian.

2.Implementasi prinsip kehati-hatian dalam hukum perbankan Pada ayat (1) dijelaskan bahwa ketentuan-ketentuan perbankan yang memuat prinsip kehati-hatian bertujuan untuk memberikan rambu-rambu bagi penyelenggaraan kegiatan usaha perbankan guna mewujudkan sistem perbankan yang sehat. Mengingat pentingnya tujuan mewujudkan sistem perbankan yang sehat, maka peraturan-peraturan di bidang perbankan yang ditetapkan oleh Bank Indonesia harus didukung dengan sanksisanksi yang adil. Pengaturan bank berdasarkan prinsip kehati-hatian tersebut disesuaikan pula dengan standar yang berlaku secara internasional.

\section{DAFTAR PUSTAKA}

Adiwarman A. Karim, Bank Islam Analisis Fiqih dan Keuangan. PT Raja Grafindo Persada, Jakrta, 2006.
Dwisanti Wulandari, Prinsip Kehati-hatian Dalam Perjanjian Kredit Bank, Tesis, Universitas Diponegoro, Semarang, 2009, diakses tanggal 26 April 2019

Gatot Supramono, Perbankan dan Masalah Kredit; Suatu Tinjauan Yuridis, Djambatan, Jakarta, 1995, hlm. 33-34 Hermansyah, Hukum Perbankan Nasional Indonesia, (Jakarta: Kencana Prenada Media Grup,2008).

Irham Fahmi, Pengantar Perbankan: Teori dan Aplikasi, Alfabeta, Bandung, 2014, hlm. 15 .

Ismail, Akuntansi Bank Teori dan Aplikasi Dalam Rupiah, (Jakarta: Kencana,2013),

Muhammad Firdaus NH, Sofiniyah et.al, Konsep dan Implementasi Penerbit Renaisan Jakarta., cetakan: 1, Oktober 2005, hlm 69. 